\title{
SiM
}

\section{Andean Pastoral Women in a Changing World: Opportunities and Challenges}

\author{
By Corinne Valdivia, Jere L. Gilles, and Cecilia Turin
}

\section{On the Ground}

- The high Andes of South America include rangelands where pure pastoralists herd llama and alpaca and agropastoralists produce tubers, grains, sheep, and cattle.

- Women of the Aymara ethnic group live in both pastoral and agro-pastoral systems and have traditionally been responsible for many aspects of crop and livestock management. They also have ownership rights for land and most types of animals.

- The Aymara have adapted to large political and economic changes. Leadership profiles for women are increasing as rural communities diversify, men migrate in search of work, and females gain access to formal education.

- The way forward is to continue to engage Aymara women in ways that encourage their participation in development processes, yet minimize additional, work-related burdens.

Keywords: Aymara, Southern Altiplano Puno Peru, Umala Municipality Central Altiplano Bolivia, human capital, political capital, livelihood diversification, climate change, evolving markets.

\section{Pastoras andinas en un mundo cambiante: oportunidades y desafíos}

\section{Perspectiva desde el campo:}

- Los altos Andes de América del Sur incluyen pastizales y tierras silvestres en las que las pastoras llevan a apacentar llamas y alpacas, en tanto que las agropastoras producen tubérculos, cereales, ovejas y ganado vacuno.

- Las mujeres del grupo étnico aymara viven en sistemas tanto pastorales como agropastorales y han sido tradicionalmente responsables de muchos aspectos del manejo agropecuario. También tienen derechos de propiedad sobre la tierra y la mayoría de los tipos de animales.

- Los aymaras se han adaptado a grandes cambios políticos y económicos. Los perfiles de liderazgo para las mujeres van en ascenso, a medida que las comunidades rurales se diversifican, los hombres emigran en busca de trabajo y las mujeres acceden a la educación formal.

- El camino hacia adelante debe seguir involucrando a las mujeres aymara en formas que alienten su participación en los procesos de desarrollo, pero que reduzcan al mínimo las cargas de trabajo adicionales.

I $\mathrm{n}$ the semiarid zones of the Andean region, women have traditionally played key roles in the management of livestock and pastures and in the marketing of household products. Research has documented how women manage rangelands, herd animals, and participate in markets. ${ }^{1-4}$ The traditions of the Aymara people in the Altiplano of southern Peru and northwest Bolivia have emphasized complementary gender roles and joint decision-making or chachawarmi ${ }^{5}$ In this sense, indigenous gender roles in the Andes might be less male-centered than gender roles described in Mexico and elsewhere. ${ }^{6}$ However, more than 500 years of domination by Spanish-speaking elites having a male-centered culture have eroded such traditions. For example, government programs have worked primarily with men; women rarely speak at community meetings, public decisions are usually taken by men, girls are less likely to go to school, and domestic violence is a serious problem. Nonetheless, the traditional notion of gender complementarity is still illustrated by the fact that both Aymara men and women can inherit land and animals, as well as women's continued dominance of small-scale commerce.

In this paper, we examine how recent social and environmental changes present new opportunities and challenges for Aymara women in two regions of the Altiplano. The Aymara 
people are the dominant indigenous group in the region. They have largely been a poor, rural population that has been marginalized by various governments over a long period of time. We draw on over 20 years of research that has been informed by participatory assessments, surveys, and ethnographic field methods. We first describe two production systems, the agropastoral system and the pastoral system. Next, we describe the changing context of markets, climate, and other factors that impact these production systems. We then present two stories to illustrate the empowerment of women. Finally, we discuss how the women are adapting and creating change for themselves and point to a way forward.

\section{Altiplano Production Systems}

Pastoral and agropastoral production systems cover the landscapes of the Altiplano, the high plateau between the mountain ranges that comprise the Andes. Depending on the altitude, people combine crop production-mainly potatoes, other tubers, and quinoa - with production of alpaca, llama, sheep, or cattle (Fig. 1). Between 3,700 and 4,000 $\mathrm{m}$ there are agro-pastoral systems, whereas between 4,000 and 5,000 m, the systems are solely based on livestock. Livestock production in the agro-pastoral systems focuses on cattle and sheep, and that of the purely pastoral systems concentrates on alpaca and llama. Most cattle and sheep are criollo-descendants of animals introduced by the Spanish. The criollo stock are well adapted to the region, but are small-bodied and not highly productive. Producers in the Altiplano must deal with a severe climate. Frequent frost and hail storms make crop and animal production risky. Drought and flooding are also common.

Diversification of crop and livestock production-as well as diversification of livelihoods-are important risk-management strategies for the Aymara. The main sources of income in agropastoral communities are derived from sales of crops, animal products, and live animals. Animals also are an important savings account for families. All families depend mostly on their own labor to farm and rear animals. The significance of each productive activity, as well as the total amount of household wealth, varies according to where people live. In pastoral communities, the production systems are less diverse, but families rely on family members' income from off-farm activities. People migrate to seek work and send remittances back home; this can be a vital source of income.

Public education-and fluency in Spanish-is another factor that strongly influences the trajectory of production systems in the Altiplano. Spanish is the national language of both Bolivia and Peru, and until recently was the only language taught in the public schools. A significant proportion of the Aymara population, however, still does not speak Spanish. For example, around $10 \%$ of the men and 30\% of the women in our Bolivian study area only speak Aymara. Non-Spanish speakers tend to be older and have had limited schooling. Lower rates of Spanish speaking among women also reflect the reluctance of previous generations to invest in
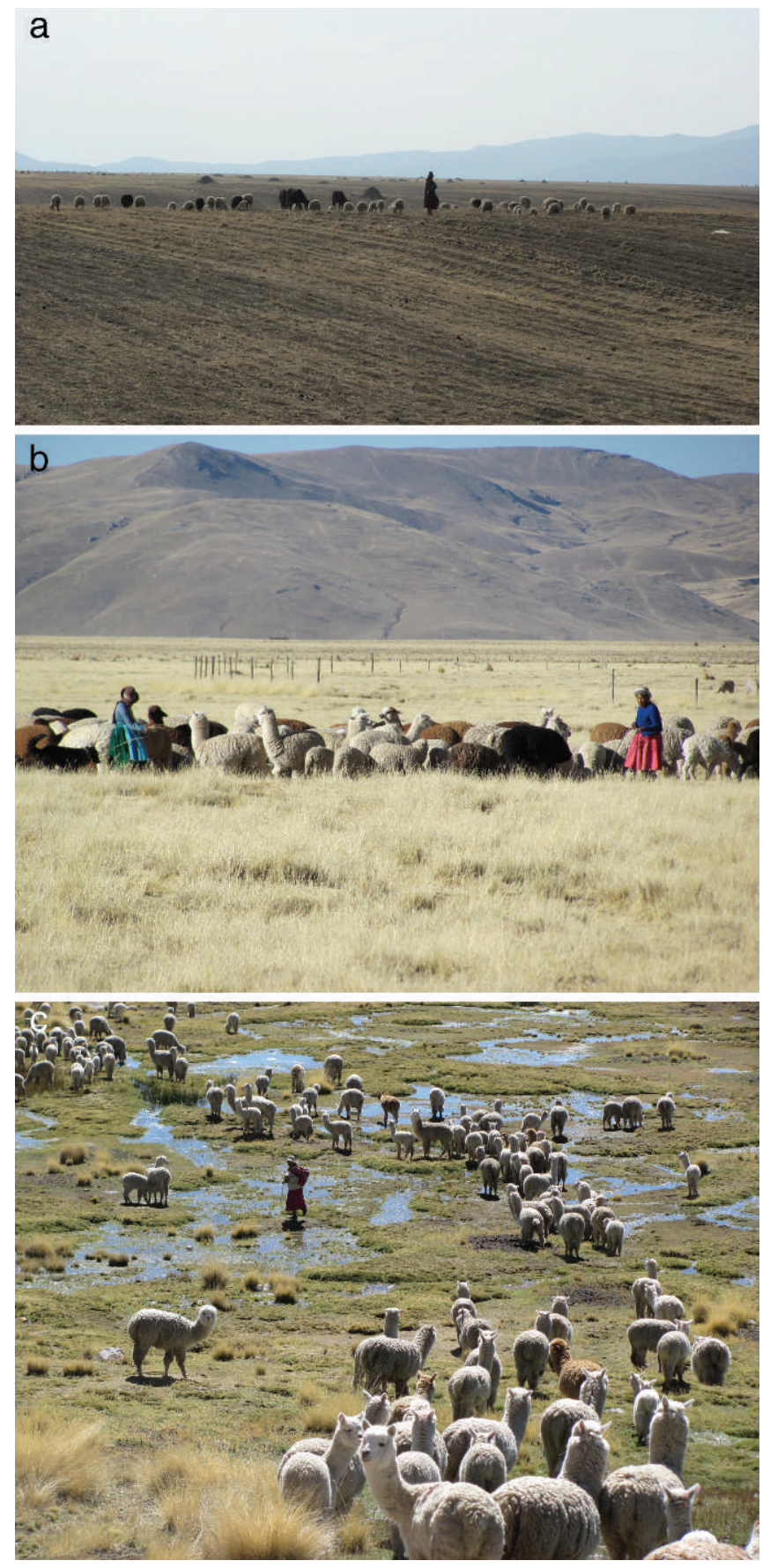

Figure 1. Images of the Altiplano. a, Pastoralist woman grazing sheep and cows in crop field. b. Old pastoralist women herding camelids on grasslands. c, Young pastoralist woman herding camelids on peat bogs. Photos courtesy of Corinne Valdivia (a); Cecilia Turin (b and c).

primary education for girls. The children in our study communities have access to public education, and parents contribute labor to build schools and teacher accommodations. Children often have to walk up to half of a day to attend secondary school, and parents perceive such distances to be unsafe for their daughters to undertake. Meanwhile, the costs of education-books, uniforms, shoes, etc.-are borne by mothers who sell sheep to pay them. 
The livelihood strategies people employ to survive in the Altiplano's harsh environment are structured by their assets and activities needed to make a living. ${ }^{2}$ How people's livelihood strategies change through time sheds light on how women and men interact within households, communities, and markets to improve their wellbeing. ${ }^{7}$ How well they access and use assets determines their degree of social inclusion or exclusion. ${ }^{7}$ Assets include human capital, social networks, local knowledge, natural resources, and financial or physical capital. For example, families use their social relations to access labor, land, and animals. These informal institutions are important for sustaining livelihoods and family welfare. The diversity of assets helps people cope with shocks and better manage risk. ${ }^{8}$ Diversification helps people cope with uncertainty and develop sustainable livelihoods. ${ }^{9}$

Families in the Altiplano combine livelihood activities to use their labor effectively, as well as to ensure multiple sources of income. Aymara women are stewards of the rangelands, because they have been traditionally in charge of livestock herding and management. Although women are less likely to be the managers of crop production, they supply a significant amount of labor to this activity. Women typically select and conserve seed and also market food crops.

Aymara women still maintain ownership rights for both land and livestock. The major domain for animal ownership among agro-pastoral women is sheep, both criollo and improved (e.g., cross-bred) stock. These ownership rights are critical because both the sheep and cultivated plots are the lifeblood of production for agro-pastoralism. In other situations agro-pastoral women might own criollo cattle, whereas pastoral women might own llama or alpaca. Ownership of high value, cross-bred dairy cattle in agro-pastoral settings, however, tends to be in the domain of men, despite women's substantial labor in dairy enterprises. This general pattern of access to productive assets among the Aymara differs from that observed in Afghanistan, where women are largely excluded from owning either land or livestock (see Schloeder et al., this issue) or in East Africa where women can own sheep or goats, but tend to be excluded from owning cattle or camels (see Coppock et al., this issue).

Below we present findings from two communities at different altitudes-an agropastoral community in Bolivia at 3,800 m elevation and a pastoral community in Peru between 4,000 and 5,000 m elevation (Fig. 2). Both receive about 400 $\mathrm{mm}$ of annual precipitation, but the climate of the pastoral community is too harsh for crop production.

In the Bolivian site, the dominant crop is potato, followed by oats, faba beans, barley, and quinoa. Families also raise cattle and sheep, and those with access to irrigation have alfalfa to support cross-bred dairy cattle. In contrast, families in the Peruvian site only rely on the sale of animals and animal products (alpaca fiber and camelid meat). Meat is mostly sold and consumed locally, whereas the fiber is sold by households and producer cooperatives to regional traders. Although fam-

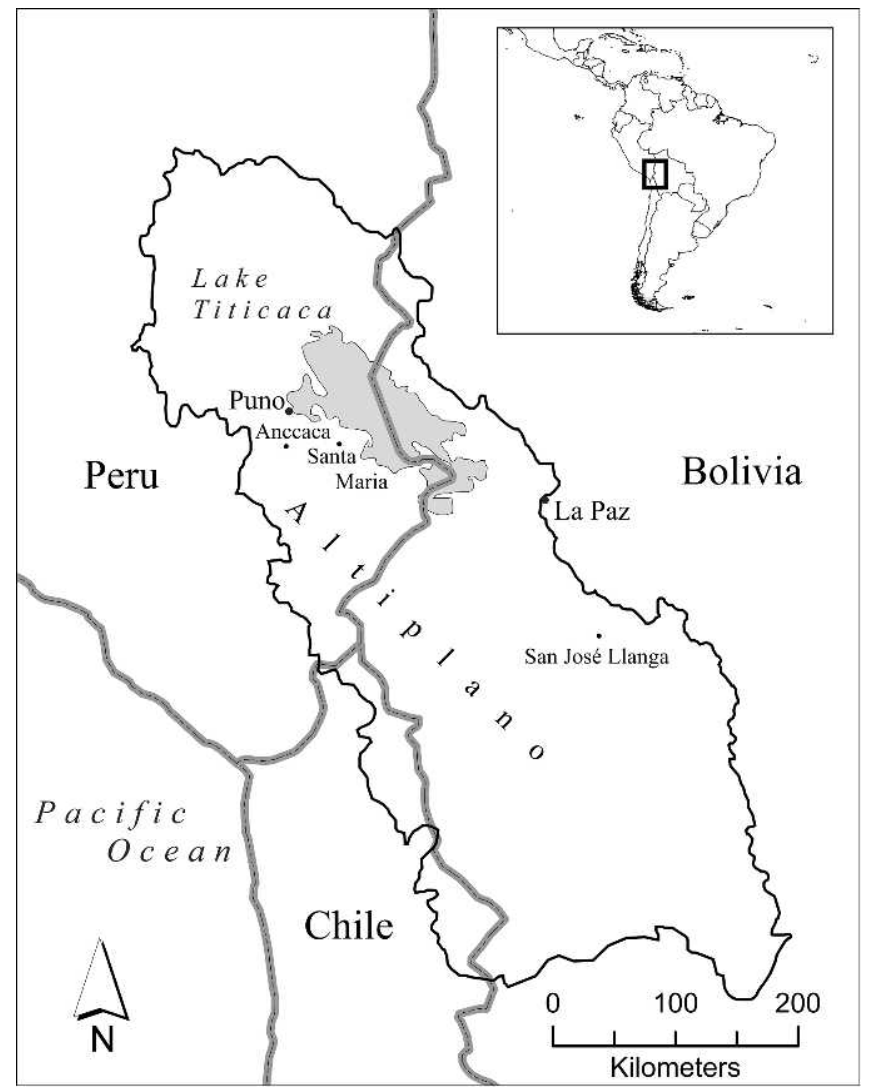

Figure 2. Map of our study sites including San José, Bolivia, and Puno, Peru. Image credit: Prepared by Dan Weber.

ily labor on-farm is very important at both sites, the Peruvian site is more dependent on migration and remittances than the Bolivian site because local options to generate income are more limiting.

\section{A Changing Context}

The Aymara people have lived on the Altiplano for centuries. They have adapted to large shifts in political systems and local economies. New challenges are occurring with respect to climate change. Below we highlight a few of the dynamics that have especially affected women. These create numerous ripple effects because women are the family caregivers and stewards of natural resources.

Recent political shifts have been notable. During the 1980s and 1990s, structural adjustment policies in Peru and Bolivia were enacted that reduced public investments in education and agricultural extension, further marginalizing rural people. Since 2000, in contrast, both governments began to favor decentralization policies that led to reinvestment in rural social services. This shift has benefited Aymara women and their families. In Puno (Peru) for example, public funds have been used to construct sheds to protect animals from cold weather, and women are participating in (and leading) new, local organizations. In Bolivia, families are benefiting from income-transfer programs and improved access to electricity and potable water. 
Although the climate has always been a source of risk for Aymara producers, the impacts of climate change have often exacerbated these risks. Climate change in the Altiplano has been well documented. ${ }^{10}$ Glaciers have been receding, a result of an increase in the mean annual temperature by one degree Celsius. Glacier melt is vital for subirrigation of livestock pastures and for some crop systems. Rainfall patterns are also changing. There are longer periods with no rain in the spring, making it more difficult to plant faba beans and quinoa, traditional sources of protein in the diet. There are less frequent, but more intense, rains during the summer when the animals are giving birth and the crops are growing-leading to losses in productivity. The warming trend is making the environment drier due to increased evapotranspiration. More clear nights during rainy seasons means an increased risk of crop-damaging frosts. Cold spells during the winter are more intense, increasing livestock mortality, particularly in pastoral communities. These changes have increased the vulnerability of Aymara households and have required that women spend more time working to support both crop and livestock production.

Economic changes have also been pervasive. In recent decades, Aymara families increasingly participate in the cash economy. Women more often participate in local markets ( $f e-$ rias) and regional markets where they negotiate transactions in the Aymara language. Because local markets are typically held on a set day each week, women can arrange in advance to leave their older children or elders in charge of the household for the day. Road construction has also facilitated market access for women. Urban markets are growing, and with them the demand for meat, milk, dairy products, and food crops, in particular.

Economic changes include a dynamic labor market. There are growing opportunities for people to leave the Altiplano to find wage employment in large cities such as $\mathrm{La}$ Paz in Bolivia. Migration patterns differ by region, but most migrants are male members from rural households who are often more educated and physically stronger than women. This enables males to pursue skilled jobs requiring literacy or unskilled jobs requiring physical labor. It also increases the responsibilities of women back home as farmers and community members. As Boserup ${ }^{11}$ observed, migration changes the dynamics of decision making within households. Due to the absence of men, women not only assume greater responsibility for making decisions about the management of natural resources and the sale of animals, but also must represent the family in community meetings and assume community leadership roles.

\section{Stories About the Empowerment of Aymara Women}

\section{San José, Bolivia}

When we started to work with people in this agropastoral community back in 1992 it took women 5 hours to get to market; they did this once per week. ${ }^{8,12}$ Today, it takes them 30 minutes. What changed? New roads facilitated access to vehicle transport so women no longer have to walk. This is a community that has experienced a transformation from a subsistence reliance on criollo sheep, criollo cattle, and potatoes in 1992 to one that was well diversified to include cash crops and subsistence crops with market integration by $2007 . .^{13-15}$

This largely occurred as a result of policies that supported small-holder dairy production and the associated extension services. High incentives to produce milk led to adoption of cross-bred dairy cows and the expansion of subirrigated alfalfa production. Today, the community sells dairy products to a wide variety of buyers and invests in production of other cash crops. Sales of dairy products have provided reliable access to cash, which in turn has provided insurance to help protect families against crop losses due to frosts or drought.

The increased emphasis on dairying demanded more time from women to help tend and milk the new cross-bred dairy cattle - as they continued to care for their criollo sheep and support crop cultivation. Burdens on women tended to increase early on during this transformative period, but women responded well in terms of embracing new tasks and making new decisions. For example, when crops failed due to a frost, families who had dairy cattle could buy more seed and replant. These decisions have been made by women. The expansion of alfalfa production not only supported the dairy cows, but also allowed women to introduce larger, cross-bred sheep (that also required nutritious forage), and increased the value of the sheep assets they already fully controlled. Because the women traditionally were the key decision-makers about potato production and marketing - in addition to the sheep-they then had the power to start to work closely with their husbands to help make new decisions about purchases of the high-value, cross-bred dairy cattle, which have become the economic engine of the community. Today, households where men and women work closely together tend to be cases where both spouses are more educated. They also tend to have higher levels of income compared to households where men or women operate independently. As a well-diversified base of livestock production has become more important to manage risk at San José, the bargaining power of the women has subsequently improved. Formal education - and the ability to speak Spanishhas also allowed women to engage with larger urban markets where commodity prices are higher. It has also allowed them to expand their participation in local government.

\section{Puno, Peru}

Women in the high-elevation pastoral systems have always had significant responsibilities in terms of resource management and decision making. However, as previously noted, women have increased their leadership profile in Puno as a result of migration by men. ${ }^{1}$ Unlike the small-holder dairy market at San José, the market for camelid fiber and meat at Puno has held little promise. Prices have been low and only a few buyers dominate the market. Although women typically have been in charge of camelid production and do most of the 
herding with support from elderly family members and children, the absence of men has meant that women now have even greater roles in activities such as livestock marketing and water-resource management.

When the women first realized that fiber prices were low at Puno, they started to produce and sell more live animals and meat in the local town of Mazocruz. This town has significantly changed in the last 30 years. Regionalization policies - previously mentioned-have revitalized the region, and Mazocruz is now a seat of government. There is also more access to formal education in Mazocruz. The construction of a highway connecting Puno and the coast has contributed to growth of local markets and facilitated male migration.

Women are also engaging more in handicraft production, which adds value to alpaca fiber. Because the prices they were obtaining for raw fiber were so low, the women decided to make better use of it themselves. Although knitting per se is not very profitable, it has significantly increased income derived from alpaca fiber. Handicrafts are sold in Mazocruz.

According to a recent survey, about $50 \%$ of the rangeland at Puno is now managed by women alone, while $29 \%$ is managed by men alone, and $20 \%$ is jointly managed by men and women. Women are becoming better educated and informed about natural resource issues, and they are starting to occupy leadership positions that deal with natural resources and climate change. ${ }^{16}$ One local leadership example deals with the all-important water use fees- the fee collector now is a woman. As in San José, the women of Puno are starting to participate in political movements and run for positions in local government. All of these trends have been supported by the expansion of local educational opportunities for women and girls.

\section{How Women Are Creating Change for Themselves}

Our work particularly illustrates how the interplay of economy and politics has affected the lives of Aymara women. Most of this has been positive. Increased involvement in markets has tended to benefit women, although the changes in women's roles and responsibilities are quite complex and depend in part on the livelihood strategy taken.

In Peru, and to a lesser extent in Bolivia, market integration has meant a livelihood strategy where male household members seek off-farm work. Where the migration of males is an important strategy, women have become the principal decision-makers for resource management and the marketing of household products. In the areas of marketing and livestock management you often see women enhancing their leadership and managerial profiles.

Access to education is a key to making more informed decisions, improving power relations within the household, and it allows women to be better informed about markets and other opportunities. Households where both men and women are more educated also have greater income earnings. The larger markets where the best prices are obtained are spaces where both Spanish and Aymara are spoken, and persons who are not bilingual operate at a significant disadvantage. Education not only provides general literacy and access to Spanish, but also provides the tools to better understand how mainstream institutions work. As Aymara women become better educated and informed, they begin to occupy leadership positions in local government. It is the combined effect of migration and education that has led to the empowerment of women. Otherwise, migration would only mean an increase on the demands on women's time and energy without empowerment.

Women have become the key decision makers in the communities with which we have worked. Their decisions at the household and local levels have a direct impact on the formation of capital - specifically human capital (their educated children) and natural capital (rangelands and water). Finally, more women are becoming agents of change in their communities, where they are taking on leadership positions and supporting educational initiatives. However, there are many challenges ahead. Some of the practices necessary to conserve natural resources take time- which is increasingly scarce for women-especially if they can't afford to hire people. This points to the problem of adding new burdens to women who might already be over-worked. For women in these communities, the challenge is not only the triple burden of reproductive, productive, and leadership activities, but it is to handle these burdens on incomes of $\$ 2-4$ US per day. A global perspective on the multiple burdens undertaken by women is discussed in the synthesis paper by Coppock et al. (in this issue).

\section{The Way Forward}

With education, the role of women is expanding into areas traditionally held by men. These changes in women's roles imply a revision in the approaches that development and extension project managers must take when dealing with communities. Although in customary settings such as communal meetings many women might not express themselves out of respect for traditional norms, they will engage in other settings (Fig. 3). As we continue to collaborate with rural communities, our participatory research includes reflection to ensure that women, especially those who are vulnerable, are engaged.

Along with policies that ensure that the local schools provide a quality education, the skills that education provides are essential as women engage with outside organizations to identify economic activities and build their political capital for civic engagement. We found that Saturdays or Sundays-or nonmarket days - are more convenient for women to engage with projects because their children can take over some of the household duties. We must always keep in mind that the management of rangelands here is essentially a feminine activity, and it is becoming more so. Therefore, equal attendance of men and women in development projects might be a minimum threshold for effective gender engagement. Aymara women are overworked, and therefore interventions that require more la- 

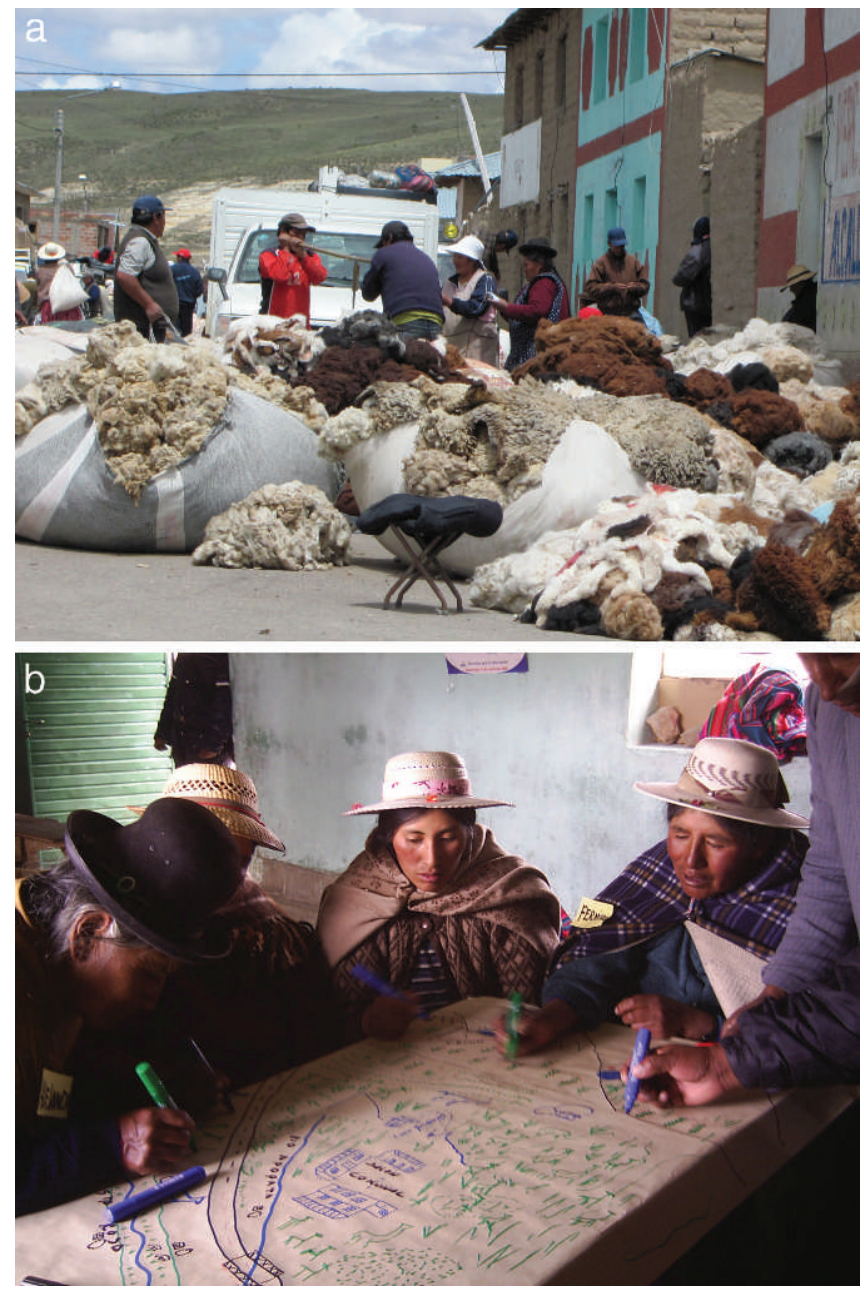

Figure 3. Aymara women engaged in participatory research conducted by the authors. a, Women negotiating the alpaca fiber in the local market of Mazocruz. b. Pastoralist women evaluating their natural resources in a participatory workshop. Photos courtesy of Cecilia Turin.

bor investments from women will not be accepted. On the other hand, interventions that effectively increase the economic opportunities of women or support their engagement in civil society will contribute to their ability to act as change agents.

Research observations of several communities over the past two decades confirm that Aymara women are reaching new heights as influential resource managers, household decision-makers, and community leaders. As we continue to engage with women and men in these pastoral and agropastoral systems, efforts have to be made to expand the spaces where women can have a voice.

\section{Acknowledgments}

We thank all the people from the communities who participated in this research throughout the years in Bolivia and Peru and all our collaborators. We also want to thank the Society for Range Management Board of Directors and the International Affairs Committee for travel support for Valdivia to present at the 2013 symposium "Women as Change Agents in the World's Rangelands" in Oklahoma City, Oklahoma. That presentation formed the basis of this article. Special thanks to Layne Coppock for editing assistance and encouragement as well as two anonymous reviewers for their comments, edits, and suggestions. All remaining errors remain the responsibility of the authors.

\section{References}

1. Turin, C., And C. Valdivia. 2011. Off-farm work in the Peruvian Altiplano: seasonal and geographic considerations for agricultural and development policies. Chapter 10. In: S. Deveraux, R. Sabates-Wheeler, and R. Longhurst [EDs.]. Seasonality, Rural Livelihoods, and Development. London, UK: Routledge. p. 143-160.

2. VAldivia, C. 2001. Gender, livestock assets, resource management, and food security: lessons from the SR-CRSP. Agriculture and Human Values 18(1):27-39.

3. Markowitz, L. 1995. Gender and resource management in an Andean agropastoral system. In: D. Shenk [ED.]. Race, gender and political activism: the legacy of Sylvia Forman. Washington, DC, USA: American Association for Feminist Anthropology. p. 145-160.

4. CAro, D. 1991. The socioeconomics and cultural context of Andean pastoralism. Chapter 4. In: C. Valdivia [ED.]. Sustainable crop-livestock systems for the Bolivian highlands. Columbia, MO, USA: University of Missouri Press. p. 71-93.

5. Burman, A. 2011. Chachawarmi: silence and rival voices on decolonization and gender politics in Andean Bolivia. Journal of Latin American Studies 43:65-91.

6. Radel, C., B. Schmook, J. McEvoy, C. Méndez, and P. Petrzelka. 2012. Labour migration and gendered agricultural relations: the feminization of agriculture in the Ejidal sector of Calakmul, Mexico. Journal of Agrarian Change 12(1):98-119.

7. Valdivia, C., ANd J. Gilles. 2001. Gender and resource management: households and groups, strategies and transitions. $\mathrm{Ag}-$ riculture and Human Values 18(1):5-9.

8. VAldivia, C., E. Dunn, And C. Jetté. 1996. Diversification as a risk management strategy in an Andean agropastoral community. American Journal of Agricultural Economics 78(5):13291334.

9. Valdivia, C., A. Seth, J. L. Gilles, M. García, E. Jiménez, J. Cusicanqui, F. Navia, and E. Yucra. 2010. Adapting to climate change in Andean ecosystems: landscapes, capitals, and perceptions shaping rural livelihood strategies and linking knowledge systems. Annals of the Association of American Geographers 100(4):818-834.

10. Seth, A., J. Thibeault, M. García, and C. Valdivia. 2010. Making sense of 21st century climate change in the Altiplano: observed trends and CMIP3 projections. Annals of the Association of American Geographers 100(4):835-865.

11. Boserup, E. 1989. Population, the status of women, and rural development. Population and Development Review 15:45-60.

12. Сорpock, D. L., And C. Valdivia. 2001. Sustaining agropastoralism on the Bolivian Altiplano: the case of San José Llanga. Davis, CA, USA: International Livestock Research Institute 
and the Global Livestock Collaborative Research Support Program. 292 p.

13. Valdivia, C., E. Jiménez, and A. Romero. 2007. E1 impacto de los cambios climáticos y de mercado en comunidades campesinas del Altiplano de La Paz (The impact of climate and market changes in peasant communities of the Altiplano of $\mathrm{La}$ Paz) Umbrales 16:233-262.

14. Jiménez, E., And C. VAldivia. 2009. Market integration: the challenge of climate change. In: Sustainable livelihoods highlights: research findings for development policymakers and practitioners. Brighton, UK: Institute of Development Studies Global Knowledge Services. p. 5.

15. Valdivia, C. 2004. Andean livelihoods and the livestock portfolio. Culture and Agriculture 26(1):19-29.

16. Rivera, E. 2010. Cambio climático en comunidades Aymaras: percepciones y efectos en la producción agropecuaria en las comunidades de Santa María y Apopata (Puno) (Climate change in Aymara communities: perceptions and effects on the agropastoral production of Santa Maria and Apopata communities [Puno]) In: P. Ames, and V. Caballero [EDs.]. Perú: el problema agrario en debate. SEPIA XIII. p. 374-401.

Authors are Associate Professor, Dept of Agricultural and Applied Economics, University of Missouri, Columbia, MO 65211,
USA, ValdiviaC@Missouri.edu (Valdivia); Professor, Dept of Rural Sociology, University of Missouri, Columbia, MO 65211, USA (Gilles); and Faculty member and Director, Institute for Smallholder Sustainable Production, National Agrarian University La Molina, Lima 33, Peru (Turin). The findings presented are from several projects: Sustainable Agropastoral Systems in Marginal Lands: Socio-Economics Research in Bolivia, funded by the Small Ruminant Collaborative Research Support Program, United States Agency for International Development (USAID), Title XII (1991-1996); Climate Variability and Household Welfare in the Andes: Farmer Adaptation and Use of Weather Forecasts in Decision Making, funded by the National Oceanic and Atmospheric Administration (NOAA) Human Dimensions Program, Dept of Commerce, USA (1999-2003); and Adapting to Change in the Andean Highlands: Practices and Strategies to Address Climate and Market Risks in Vulnerable Agro-Ecosystems, funded by the Sustainable Agriculture and Natural Resource Management Collaborative Research Support Program (SANREM CRSP) USAID Title XII (2006-2010). Funding was also provided by the University of Missouri, Columbia, Missouri, USA.

Rangelands 35(6)75-81

DOI: 10.2111/RANGELANDS-D-13-00038.1

(C) 2013 The Society for Range Management 